\title{
Associations of antenatal glucocorticoid exposure with mental health in children
}

Elina Wolford ${ }^{1}$, MA, Marius Lahti-Pulkkinen ${ }^{1,2}, \mathrm{PhD}$, Polina Girchenko ${ }^{1}$,MSc, Jari Lipsanen ${ }^{1}$,MA, Soile Tuovinen ${ }^{1}$, PhD, Jari Lahti ${ }^{1,3,4}, \mathrm{PhD}$, Kati Heinonen ${ }^{1}, \mathrm{PhD}$, Esa Hämäläinen ${ }^{5}$, MD, PhD, Eero Kajantie $^{6,7,8}, \mathrm{MD}, \mathrm{PhD}$, Anu-Katriina Pesonen ${ }^{1}, \mathrm{PhD}$, Pia M Villa ${ }^{9}$, MD, PhD, Hannele Laivuori $^{10,11,12,13}$, MD, PhD, Rebecca M Reynolds ${ }^{2}, \mathrm{MD}, \mathrm{PhD}$, Katri Räikkönen ${ }^{1}, \mathrm{PhD}$

Affiliations:

${ }^{1}$ Department of Psychology and Logopedics, Faculty of Medicine, University of Helsinki, Helsinki, Finland;

${ }^{2}$ University/British Heart Foundation Centre for Cardiovascular Science, Queen's Medical Research Institute, University of Edinburgh, Edinburgh, UK;

${ }^{3}$ Helsinki Collegium for Advanced Studies, University of Helsinki, Helsinki, Finland;

${ }^{4}$ Folkhälsan Research Centre, Helsinki, Finland;

${ }^{5}$ Department of Clinical Chemistry, University of Helsinki, Helsinki, Finland;

${ }^{6}$ National Institute for Health and Welfare, Helsinki, Finland;

${ }^{7}$ Children's Hospital, Helsinki University Hospital and University of Helsinki, Helsinki, Finland;

${ }^{8}$ PEDEGO Research Unit, MRC Oulu, Oulu University Hospital and University of Oulu, Oulu, Finland;

${ }^{9}$ Obstetrics and Gynaecology, Helsinki University Hospital and University of Helsinki, Helsinki, Finland;

${ }^{10}$ Faculty of Medicine and Life Sciences, University of Tampere, Tampere, Finland;

${ }^{11}$ Department of Obstetrics and Gynecology, Tampere University Hospital, Tampere, Finland; 
${ }^{12}$ Medical and Clinical Genetics, University of Helsinki and Helsinki University Hospital, Helsinki, Finland;

${ }^{13}$ Institute for Molecular Medicine Finland, Helsinki Institute of Life Science, University of Helsinki, Helsinki, Finland.

Corresponding author: Elina Wolford, Department of Psychology and Logopedics, Faculty of Medicine, University of Helsinki, Helsinki, Finland; Haartmaninkatu 3, P.O. Box 21, 00014 University of Helsinki, [elina.wolford@ @elsinki.fi], +358 504486896.

Key words: Glucocorticoids, betamethasone, mental health, developmental milestones, psychiatric problems. 


\section{Abstract}

\section{Background}

Synthetic glucocorticoids, to enhance fetal maturation, are a standard treatment when preterm birth before 34 gestational weeks is imminent. While morbidity- and mortality-related benefits may outweigh potential neurodevelopmental harms in children born preterm $(<37$ gestational weeks $)$, this may not hold true when pregnancy continues to term ( $\geq 37$ gestational weeks). We studied the association of antenatal betamethasone exposure on child mental health in preterm and term children.

\section{Methods}

We included 4,708 women and their children, born 2006-2010, from the Prediction and Prevention of Pre-eclampsia and Intrauterine Growth Restriction (PREDO) Study with information on both antenatal betamethasone treatment and child mental and behavioral disorders from the Finnish Hospital Discharge Register from the child's birth to December $31^{\text {st }} 2016$. Additional follow-up data on mother-reported psychiatric problems and developmental milestones were available for 2,640 children at $3.5(\mathrm{SD}=0.07)$ years-of-age.

\section{Results}

Of the children, 187 were born preterm (61 betamethasone-exposed) and 4,521 at term (56 betamethasone-exposed). The prevalence of any mental and behavioral, psychological development, emotional and behavioral, and comorbid disorders was higher in the betamethasone-exposed, compared to non-exposed children [Odds Ratio 2.76 (95\% Confidence Interval 1.76,4.32), 3.61 $(2.19,5.95), 3.29(1.86,5.82)$, and $6.04(3.25,11.27)$, respectively]. Levels of psychiatric problems and prevalence of failure to meet the age-appropriate development in personal-social skills were also higher in mother-reports of betamethasone-exposed children. These associations did not vary significantly between preterm and term children. 


\section{Conclusions}

Antenatal betamethasone exposure may be associated with mental health problems in children born preterm and in those who end up being born at term. 


\section{Introduction}

Fetal overexposure to maternal endogenous or synthetic glucocorticoids (sGC) may play a key role in offspring neurodevelopmental programming (Seckl \& Meaney 2004). Fetal cortisol levels are up to 10 times lower than maternal levels. This is ensured by the placental glucocorticoid barrier enzyme, 11 beta hydroxysteroid dehydrogenase type 2 (11ß HSD2), which converts $80-90 \%$ of active maternal cortisol to its inactive form (Seckl \& Meaney 2004). While lower levels of active cortisol are necessary for normal brain development, fetal cortisol overexposure may harm several neurodevelopmental processes, and hence harm the developing brain with potential adverse sequelae on mental health (Damsted et al. 2011).

The average prevalence of preterm delivery in developed regions in 2010 was $8.6 \%$ (Blencowe et al. 2012), with $7-10 \%$ of women at risk of preterm delivery being administered sGCs, such as betamethasone or dexamethasone (Reynolds \& Seckl 2012). In high-resource settings the treatment carries substantial benefits for infants born before 34 weeks of gestation: incidence of respiratory distress syndrome has been shown to decrease by $34 \%$, intraventricular hemorrhage by $46 \%$, and neonatal mortality by $31 \%$ (March of Dimes, PMNCH \& WHO 2012). Also those born late preterm (births between 34-36 weeks of gestation) may gain similar respiratory benefits of antenatal sGCs (Gyamfi-Bannerman et al. 2016). There is, thus, wide consensus that these benefits outweigh the potential longer-term harms sGCs may carry on individuals born preterm. Yet, prediction of preterm birth is uncertain, and many sGC-exposed infants end up being born at term. While some evidence suggests that also those born early-term (births between 37-39 weeks of gestation) after caesarean sections (Stutchfield 2005) may benefit from antenatal sGS in short-term (KamathRayne et al. 2016; Saccone \& Berghella 2016; The American College of Obstetricians and Gynecologists 2016; Sweet et al. 2017), it still remains unclear whether the short-term benefits 
related to sCGs equally outweigh the potential longer-term harms on neurodevelopment and mental health in individuals born at term (Reynolds \& Seckl 2012).

Human evidence supporting this argument in individuals exposed to antenatal sGCs and who ended up being born at term is still scarce and study findings are mixed. In one randomized controlled trial (RCT), term-born children exposed prenatally to multiple (up to 4) courses of sGC had a higher rate of, and more severe, neurosensory disabilities at 5 years compared to peers exposed to a single course of sGC (Asztalos et al. 2014). Another RCT found no differences in behavior problems between 8-15-year-old term-born children exposed prenatally to a single course of betamethasone and those not exposed to sGCs, though schools did report more learning difficulties in those exposed (Stutchfield et al. 2013). In addition, two observational studies reported no differences between exposed and non-exposed term-born children in the levels of affective problems at the age of 6-10 years (Davis et al. 2013), or in intelligence at 6-11 years (Alexander et al. 2016). Finally, in one additional observational study those term-borns exposed to sGCs displayed higher salivary cortisol stress reactivity to a standardized psychosocial stress test than their non-exposed term-born peers at 6-11 (Alexander et al. 2012) and at 14-18 (Ilg et al. 2018) years of age.

The mixed findings may result from different study designs, differences in the number of sGC courses administered, and the use of varying measures of mental health and psychological development at ages that vary in developmental stage. Further, only one of these previous studies has examined the possible confounding of maternal obesity and common pre-pregnancy and pregnancy disorders (Alexander et al. 2016). These disorders often underpin the risk of preterm birth (Rosenberg et al. 2005; Goldenberg et al. 2008), and hence co-occur with antenatal sGC treatment. 
In a well-characterized cohort of Finnish women and their children, we examined the association of antenatal betamethasone exposure with early childhood mental and behavioral disorders and mother-reported psychiatric problems and developmental milestones. We examined if these associations varied by whether the children were born preterm or at term. We also took into account maternal early pregnancy obesity, gestational and type 1 diabetes, gestational and chronic hypertension and pre-eclampsia, and tested if the association of antenatal betamethasone exposure with early childhood mental and behavioral disorders and mother-reported psychiatric problems and developmental milestones varied by sex, as one of the previous studies in term-born children showed that the effects of sGC treatment on stress reactivity might show sex-specificity (Alexander et al. 2012).

\section{Method}

\section{Participants}

The Prediction and Prevention of Pre-eclampsia and Intrauterine Growth Restriction (PREDO) study comprises 4,777 mothers who gave birth to a singleton liveborn child in Finland 2006-2010 (Girchenko et al. 2017). Recruitment took place at ten study hospitals in Southern/Eastern Finland at the first ultrasound screening between 12+0-13+6 weeks+days-of-gestation. The original study cohort comprises three subgroups: 969 pregnant women with known clinical risk factors for preeclampsia and IUGR, 110 women with no known risk factors for these conditions, and 3,698 women who were recruited whether or not they had risk factors for pre-eclampsia and IUGR (Girchenko et al. 2017). From the latter group two women have since withdrawn consent. 
Diagnoses on mental and behavioral disorders from child birth up to December $31^{\text {st }} 2016$ were available from 4,752 children. Of them, 4,708 also had information on antenatal betamethasone exposure and other important pregnancy and perinatal characteristics. At the end of the register follow-up the children were 6-10 years-of-age (Mean=7.7, standard deviation $[\mathrm{SD}]=0.8$ ).

Additional information on mother-reported child psychiatric problems and developmental milestones were available from a follow-up conducted in 2011-2012. Mother-reported data on child psychiatric problems and/or developmental milestones and data on antenatal betamethasone exposure and other important pregnancy and perinatal characteristics were available for 2,640 children at 1.9-5.9 years-of-age (Mean=3.5, $\mathrm{SD}=0.7$ ). See online Supplementary Fig $\mathrm{S} 1$ for the sample and attrition.

Compared to the initial sample from whom we missed child disorders or betamethasone/pregnancy/perinatal data $(\mathrm{N}=67)$, the ones with these data available $(\mathrm{N}=4,708)$ were born to mothers who $8.7 \%$ less often smoked during pregnancy, $9.3 \%$ less often had chronic hypertension, and 5.8\% more often had gestational hypertension; the children themselves were born $5.8 \%$ less often preterm (all $p$-values<0.04). Compared to the invited non-participants of the 20112012 follow-up ( $\mathrm{N}=1,945)$, the 2011-2012 follow-up study participants $(\mathrm{N}=2,640)$ were born to mothers who were 0.7 -years-older at delivery, $10.1 \%$ more often had a tertiary education, $2.1 \%$ less often were single, $5.7 \%$ more often primiparous, $1.4 \%$ less often had chronic hypertension, $5.2 \%$ less often smoked during pregnancy, had $0.5 \mathrm{~kg} / \mathrm{m}^{2}$ lower early pregnancy body mass index (BMI) and were $3.3 \%$ less often obese (all $p$-values $<0.01$ ). 
All participating women signed informed consents. The PREDO study protocol was approved by the Ethics Committees of the Hospital District of Helsinki and Uusimaa and by the participating hospitals.

\section{Exposure to synthetic glucocorticoids}

Information on betamethasone treatment (yes/no) was extracted from medical records and/or the Finnish Medical Birth Register (MBR). For a subset of women who were recruited based on their risk factor status for pre-eclampsia and IUGR, we had information on the number of courses $(\mathrm{N}=43$; Mean $=1, \mathrm{SD}=0.4$, range $0.5-2$ courses of $2 \times 12 \mathrm{mg}$ per course $)$ and the timing of the exposure $(\mathrm{N}=45$; Mean=3.5, $\mathrm{SD}=3.9$, range $0-13$ weeks before delivery).

\section{Child Mental and Behavioral Disorders}

We identified diagnoses of child mental and behavioral disorders from the Finnish Hospital Discharge Register (HDR) from the child's birth between 2006-2010 to December $31^{\text {st }}$, 2016. The HDR includes primary and subsidiary diagnoses of all inpatient and outpatient visits (data on both visits available since the child's birth) coded using International Classification of Diseases-10 (ICD10) during the study period and is a valid tool for research (Sund 2012). We analyzed those disorders which included children in the betamethasone-exposed and non-exposed groups born preterm and at term (Table S1); children with no disorders were used as the referent in all analyses ( Table S1).

\section{Mother-reported child psychiatric problems}

The Child Behavior Checklist 11/2-5 years (CBCL) comprises 99 problem items rated on a scale of 0 (not true) to 2 (very true or often true) (Achenbach \& Rescorla 2000). The CBCL yields total, 
internalizing, and externalizing problems scores (Achenbach \& Rescorla 2000). See online Supplementary Text for internalizing and externalizing problems subscales.

\section{Mother-reported child developmental milestones}

The Ages and Stages Questionnaire-3 (ASQ) (Squires et al. 1997) measures age-appropriate developmental milestones in five domains (communication, fine motor, gross motor, problem solving ability, and personal-social functioning). Six questions in each domain indicate whether the child has mastered ('yes', 10 points), partly/inconsistently mastered ('sometimes', 5 points), or not yet mastered the milestone ('not yet', 0 points) (Squires et al. 1997). We defined mild developmental delay as scores between -1 and -2 SD below the age-appropriate mean, and failure to meet the development that is typical for the child's age as scores -2 SD or more below the ageappropriate mean for each domain (Squires et al. 1997). The ASQ is a reliable and valid screening tool for determining children in need of further developmental assessment (Kerstjens et al. 2009; Filgueiras et al. 2013; Steenis et al. 2015; Charkaluk et al. 2017).

\section{Covariates and moderators}

These included maternal age at delivery (years), parity (primiparous/multiparous), delivery mode (vaginal/caesarean section), premature rupture of membranes (yes/no), smoking during pregnancy (no/quit or smoked throughout), maternal early pregnancy BMI $\left(\mathrm{kg} / \mathrm{m}^{2}\right)$, chronic and gestational hypertension, pre-eclampsia, gestational and type 1 diabetes (all categorized yes/no), weight, length and head circumference at birth standardized by sex and gestational age (Pihkala et al. 1989) (SD units), gestational age (analyzed both as a continuous covariate and dichotomous $[<37 / \geq 37$ gestational weeks] moderator), and child's sex (analyzed both as a covariate and a moderator), which were extracted from the MBR, HDR, and/or from medical reports. Maternal alcohol use during pregnancy (yes/no), education (primary or secondary/ tertiary) and maternal history of 
physician-diagnosed asthma (yes/no), as some in this group may be taking corticosteroid inhalers, were reported in early pregnancy, and child's age (months) was reported in the follow-up. For the analyses of child mental and behavioral disorders as the outcomes, we also made adjustments for maternal any mental disorder diagnosis based on HDR inpatient and outpatient visits (any/no DSMIII-R/ICD-10 diagnosis of mental/behavioral disorder; inpatient data were available between 1987 and 2016; outpatient data were available between 1998 and 2016; birth year of the mothers varied from 1959 to 1977). For the analyses of mother-reported child outcomes, we made adjustments for maternal depressive symptoms during pregnancy (trimester-weighted mean score of bi-weekly reports) measured using the Center for Epidemiological Studies Depression Scale (CES-D) (Radloff 1977), and concurrently to rating the child using the Beck Depression Inventory-II (BDI-II) (Beck et al. 1996).

\section{Statistical analysis}

Statistical analyses were conducted by using IBM SPSS Statistics software, version 24 and SAS, version 9.4.

Since the PREDO study was not originally designed to study the effects of betamethasone treatment on child developmental outcomes, we used propensity score weighing (Austin 2011) to account for the differences in baseline characteristics associated with betamethasone treatment (Table 1). We determined the propensity score weights by logistic regression to estimate the probability of receiving betamethasone treatment conditional on the observed covariates. We then trimmed the highest propensity score weights downwards with a $95^{\text {th }}$ percentile cutpoint (Lee et al. 2011). The resulting propensity score weights were used in all analyses. Because the sample size differed between the child disorders $(\mathrm{N}=4,708)$ and mother-reported child outcomes $(\mathrm{N}=2,640)$, we calculated the propensity score weights separately for these two samples. 
Using logistic regression analysis, we tested the associations between antenatal betamethasone exposure and child main category diagnoses of mental and behavioral disorders (Table S1), and multinomial logistic regression to test associations with having just one or two to four co-morbid mental and behavioral disorders compared to no disorders. If associations with the main category disorders were significant, we specified the associations by analyzing the disorders in the specific disorder category (Table S1).

We then tested the associations between antenatal betamethasone exposure and mother-reported child total, internalizing, and externalizing problems (converted into SD units) by using generalized linear models with Gaussian reference distribution. Associations between antenatal betamethasone exposure and mother-reported child developmental milestones (scores >-1SD contrasted with scores between -1SD and -2SD and with scores $\leq-2 \mathrm{SD}$ ) were tested by using multinomial logistic regression analysis.

Analyses of child disorders as outcomes included the propensity score weights and child's sex and birth year as covariates, and mother-reported child outcomes propensity score weights andchild's sex and age at follow-up as covariates (model 1). We then added all the other covariates into the models, except for maternal mental health (model 2). Further, maternal mental disorder derived from HDR was added into the models with child disorders as outcomes, and maternal depressive symptoms during pregnancy and at the time of rating the child outcomes were added into the models of mother-reported child outcomes (model 3). To study whether birth length or head circumference SD had an effect on the findings, we re-ran models 2-3 by replacing child's birth weight SD score with birth length and head circumference SD scores as covariates. 
We entered an interaction term 'betamethasone exposure/non-exposure x preterm/term birth' into the equations to study if the betamethasone associations varied by preterm/term status, and an interaction term 'betamethasone exposure/non-exposure $\mathrm{x}$ girl/boy' into the equations to study if the betamethasone associations varied by child's sex.

\section{Results}

Table 1 shows that compared to non-exposed children, betamethasone-exposed children had lower gestational age, were more often born preterm, had lower weight, length and head circumference at birth, had lower birth weight and length SD scores, and were more often born small-for-gestational age in weight and length. They were also more often delivered by caesarean section and born from pregnancies complicated by pre-eclampsia, type 1 diabetes, obesity, and premature rupture of membranes (Table 1).

\section{Betamethasone exposure and child mental and behavioral disorders}

The prevalence of any mental and behavioral, psychological development, and behavioral and emotional disorders, and of two to four co-morbid disorders from the main diagnosis categories (Table 2) was significantly higher in the betamethasone-exposed than non-exposed children in models including the propensity score weights and all covariates (model 1 adjusted for child's sex and age; model 2 adjusted additionally for maternal BMI, hypertensive and diabetic pregnancy disorders, delivery mode, age, education, parity, smoking and alcohol use, asthma, premature rupture of membranes, and child's gestational age and birth weight SD score; and model 3 adjusted additionally for maternal mental disorders; Table 2). 
Of the specific disorders of psychological development and behavioral and emotional disorders, the prevalence of speech and language $(6.8 \%$ vs $2.9 \%, \mathrm{OR}=2.57,95 \% \mathrm{CI}=1.25$ to $5.30, p \leq 0.05$ for models including propensity score weights and adjusting for all covariates) and other disorders of psychological development $(4.3 \%$ vs $0.7 \%, \mathrm{OR}=7.26,95 \% \mathrm{CI}=2.83$ to $18.62, p<0.001$ for models including propensity score weights and adjusting for all covariates) and hyperkinetic disorders (6.0\% vs $1.4 \%, \mathrm{OR}=4.70,95 \% \mathrm{CI}=2.11$ to $10.49, p<0.02$ for models including propensity score weights and adjusting for all covariates) were significantly higher in the betamethasone-exposed than non-exposed children.

None of these associations were altered when we replaced birth weight SD score with birth length and head circumference SD scores ( $p$-values $\leq 0.05$ for models including propensity score weights and all covariates; data not shown).

The interaction analyses 'betamethasone-exposure/non-exposure x preterm/term birth' (all $p$ values $>0.27$ ) or 'betamethasone exposure/non-exposure $\mathrm{x}$ girl/boy' did not reveal any significant interactions (all $p$-values $>0.07$; data not shown).

\section{Betamethasone exposure and mother-reported child outcomes}

Betamethasone-exposure was associated with higher scores on total, internalizing, and externalizing problems in models including the propensity score weights and all covariates (models 1-3 in Table 3). See online Supplementary Table S2 for associations with internalizing and externalizing problems subscales.

The prevalence of failing to meet the development that is typical for the child's age in communication, problem solving, and personal social skills was higher in betamethasone-exposed 
compared to non-exposed children in models including the propensity score weights and child's sex and age (model 1 in Table 4). The association with personal social skills survived when adjusted for all covariates, while the association with communication and problem solving did not (models 2-3 in Table 4). The associations with total, internalizing, and externalizing problems, and with the failure to meet the development that is typical for child's age in personal social skills remained unchanged when birth weight SD score was replaced with birth length and head circumference SD scores ( $p$-values $\leq 0.03$ in models including propensity score weights and all covariates; data not shown).

The interaction analyses ‘betamethasone-exposure/non-exposure x preterm/term birth' did not reveal any significant interactions (all $p$-values $>0.12$; data not shown). Further, we found one significant betamethasone exposure/non-exposure $\mathrm{x}$ girl/boy interaction on externalizing problems $(p=0.04)$. In boys, betamethasone-exposure was associated with higher externalizing problems scores $(\mathrm{B}=0.66,95 \% \mathrm{CI}=0.28$ to $1.04, p=0.001)$ while in girls, it was not $(p=0.33)$.

\section{Discussion}

Our study shows that antenatal exposure to betamethasone may be associated with early childhood mental health problems. The prevalence of any mental and behavioral disorder, psychological development (specifically speech and language) and behavioral and emotional (specifically hyperkinetic) disorders in childhood was higher in the betamethasone-exposed than betamethasone non-exposed children. Compared to non-exposed children, the prevalence of co-morbid mental and behavioral disorders was also higher in the betamethasone-exposed children. Our study findings with mother-reported child outcomes are in alignment: compared to the non-exposed children, 
betamethasone-exposed children had higher scores on total, internalizing, and externalizing problems, and they had a higher prevalence of failing to meet the development that is typical for the child's age in personal social skills. Our findings are thus the first to show that exposure to sGCs is associated with child mental health problems that are robust and consistent across the sources of information; these harms not only relate to child mental and behavioral disorders but also to problems that are sub-threshold.

None of these associations varied significantly between those born preterm and at term. These associations, tested in the presence of propensity score weights and adjusted for a number of important covariates, including maternal pregnancy and pre-pregnancy conditions, smoking and alcohol use, education level, and premature rupture of membranes increasing the risk of preterm birth (Rosenberg et al. 2005; Goldenberg et al. 2008) and hence the risk of exposure to antenatal sGCs, as well as child's gestational age, birth weight, length, and head circumference SD score. Importantly, the associations were not either explained by maternal mental disorders derived from HDR up to the same date as the child's follow-up end-date or maternal depressive symptoms reported during or after pregnancy, which also increase the risk of preterm birth (Jarde et al. 2016) and child mental and behavioral disorders (Lahti et al. 2017; Tuovinen et al. 2018). Our findings, thus, additionally suggest that in term children, the potential benefits of antenatal sGCs may not outweigh the longer-term developmental harms. This observation is important as preterm birth is difficult to predict and a large number, in our study almost 50\%, of the women administered antenatal sGCs, continue to deliver at term. This observation assumes further relevance as antenatal sGCs may be administered also in late-preterm deliveries and early term caesarian section deliveries as a result of observations of their short-term respiratory benefits (Stutchfield 2005; Kamath-Rayne et al. 2016; Saccone \& Berghella 2016; The American College of Obstetricians and Gynecologists 2016; Sweet et al. 2017). Further, even in preterm individuals, antenatal sGCs may have different 
effects on neurodevelopment depending on individual tissue-sensitivity to sGCs (van der Voorn et al. 2015). Individual genetic variations in glucocorticoid sensitivity and exposure to antenatal sGCs have been associated with IQ and behavior in young adults born preterm (van der Voorn et al. 2015). Future studies should further examine the possibility of more tailor-made approaches in sGC dosing.

Our study findings disagree with the previous observational studies showing null effects of sGCs on affective problems (Davis et al. 2013) and intelligence (Alexander et al. 2016) in term-born children. Our findings also disagree with the RCTs which have reported null effects of sGCs on child behavior problems (Stutchfield et al. 2013; Asztalos et al. 2014) in term-born children. The RCTs have, however, shown harmful neurosensory effects in those exposed to multiple vs. a single course of sGCs (Asztalos et al. 2014), and harmful effects on learning in those exposed to a single course of sGCs vs. no exposure (Stutchfield et al. 2013). Our findings agree with a small observational study combining preterm and term children which found that those exposed to sGCs displayed more total psychiatric and inattention problems at age 8 years; These group differences were rendered non-significant at the age of 16 years (Khalife et al. 2013). This latter study did not examine if the effects varied by preterm/term birth. This precludes direct comparisons of our findings with findings of this study. Whether these harmful associations found in our study persist as the children age, is a subject of future studies.

As the placenta metabolizes sGCs poorly, they readily cross to the fetal side (Seckl \& Meaney 2004) and easily pass the blood-brain barrier (Damsted et al. 2011), carrying harmful effects on the fetal brain development. Glucocorticoids bind to glucocorticoid and mineralocorticoid receptors in the brain which are abundant especially in the hippocampus (Reul \& De Kloet 1985) and in the human fetus they are expressed already at 24 weeks of gestation (Noorlander et al. 2006). This 
corresponds with the typical timing of the administration of sGCs in clinical practice. Experimental animal studies have shown, that sGC administration can lead to a decrease in neuronal proliferation, neuronal damage and even neuronal death in the hippocampus (Noorlander et al. 2014). Given the importance of the hippocampus in learning, memory, and spatial functioning (Burgess et al. 2002), as well as neuroendocrine function (Lupien et al. 2009) and neurobehavioral problems (Geuze et al. 2005), it is plausible that hippocampus is the key target of sGC-related harms. However in a small human study, no hippocampal changes associated with exposure to sGCs were found (Modi et al. 2001). Another key target may be the cerebellum which undergoes rapid growth after 24 weeks-ofgestation. The cerebellum is highly dense in glucocorticoid receptors (Pavlík et al. 1984) and plays a role in emotion regulation and neurobehavioral development (O'Halloran et al. 2012). Studies have found that exposure to sGCs can affect cerebellar development, which subsequently, may affect cognitive development (Noguchi 2014) and mental health.

Animal models have also shown other adverse effects of antenatal sGC exposure on offspring brain development (Damsted et al. 2011), suggesting that there may be other brain mechanisms through which sGCs affect neurobehavioral development as well. In human studies, exposure to sGCs has been associated with cortical thinning especially in the rostral anterior cingulate cortex (Davis et al. 2013), which is also associated with internalizing problems (Boes et al. 2008). In addition, exposure to sGCs has been associated with decreased brain surface area and complexity of cortical folding in close to or term infants (Modi et al. 2001). Finally, a recent study found that antenatal sGC exposure is associated with reduced cord blood neurotrophin-3 (NT-3) in late preterm infants (Hodyl et al. 2016). NT-3 mediates neuronal growth, differentiation and synapse formation (Conover \& Yancopoulos 1997), and thus may provide one mechanism through which sGC exposure affects brain development and subsequent mental health. 
An additional novel finding of this study is that betamethasone appeared to exert sex-specific associations with mother-reported externalizing problems. This is of interest as boys in our and in other samples display higher scores on these problems, possibly resulting in a higher variance and statistical power to detect the associations in boys. Alternatively, this may suggestthat boys may be more susceptible to the harmful effects of sGCs. However, a previous observational study showed that the association of betamethasone with higher salivary cortisol stress-reactivity was present in 611-year-old girls (Alexander et al. 2012). In a later follow-up of this study, at age 14-18 years, the sex-specific effects in cortisol reactivity were no longer present (Ilg et al. 2018). However, this may reflect the small sample size, since only 44 of the 209 original study participants participated in the follow-up (Ilg et al. 2018). The sex-specific effects of sGC exposure have not been shown in other human studies, and findings from animal studies remain mixed (Kapoor et al. 2008). The study by Alexander et al. comprised both pre-pubertal and pubertal children (Alexander et al. 2012) while our sample was pre-pubertal. Hence, future studies are warranted to unravel if the sex-specificity of the antenatal sCG exposure differs according to the child's developmental stage.

The strengths of our study include a longitudinal study design and a well-characterized large cohort with detailed information on the maternal pregnancy and mother-child perinatal characteristics and child developmental outcome data from different sources. Further, follow-up attrition with information on mental and behavioral disorders was minimal. A further strength is that the findings were in alignment regardless of the source of information lending validity to our findings. A limitation of our study is that it was not originally designed to test the effects of antenatal betamethasone on child developmental outcomes. Yet, our study was designed to examine risk factors for pre-eclampsia and IUGR, which increase the risk for preterm birth (Goldenberg et al. 2008) and, thus, exposure to antenatal sGC. This resulted in the prevalence of pre-eclampsia in the PREDO cohort being markedly higher $(4.1 \%$ vs $0.8-1.9 \%)$ than in the Finnish general population 
(Girchenko et al. 2017). In addition, compared to the Finnish general population, the PREDO mothers had a higher prevalence of early pregnancy obesity (14.0\% vs $11.5 \%)$, gestational hypertension (4.2\% vs $3.1 \%)$ and caesarean section deliveries (17.2\% vs $15.8-16.2 \%)$, were older at delivery (31.5 vs 29.4-29.5 years), more often multiparous $61.3 \%$ vs $57.9-59.0 \%$ ), and less often smoked throughout pregnancy (5.0\% vs 11.1-11.4\%) (Girchenko et al. 2017). This may limit the generalizability of our findings. However, the gestational age and birth weight of the children in the cohort corresponded with the national average (Girchenko et al. 2017). Further, while our sample size was large and the prevalence of pre-eclampsia high, the number of children exposed to betamethasone prenatally was still relatively small. The number of children with mental and behavioral disorders was also relatively small which precluded studying rarer specific disorders. Also, our observational study design precludes causal inferences. Randomized double-blinded controlled experimental clinical trials comparing the outcomes of antenatal betamethasone exposure on child outcomes in representative study samples are needed to make causal inferences. Finally, we had information on the dose and timing of the antenatal betamethasone treatment only for a small number of study participants, precluding tests of dose- or timing-dependent effects. However, repeated betamethasone courses were not recommended during the time our cohort was born (Uotila et al. 2011). In the subsample of our study whom dosage and timing information was available, only one mother had received two courses of betamethasone.

Our findings show that the term-born sGC-exposed children have similar problems in mental health than the sGC-exposed children who are born preterm. At the moment, children born preterm are followed up regardless of whether they were exposed to sGCs or not, but there is no systematic clinical follow-up of children exposed to sGCs who end up being born at term. These findings thus carry a public health message suggesting the need to extend clinical follow-up of child mental health beyond the preterm group to the group exposed to antenatal sGCs and born at term. 


\section{Financial Support}

The PREDO study is funded by the Academy of Finland; European Commission (Horizon 2020 Award SC1-2016-RTD-733280 RECAP); European Commission Dynamics of Inequality Across the Life-course: structures and processes(DIAL) No 724363 for PremLife; EraNet Neuron; EVO (a special state subsidy for health science research); University of Helsinki Research Funds; the Signe and Ane Gyllenberg Foundation; the Emil Aaltonen Foundation; the Finnish Medical Foundation; the Jane and Aatos Erkko Foundation; the Novo Nordisk Foundation; the Päivikki and Sakari Sohlberg Foundation; the Sigrid Juselius Foundation; and the Sir Jules Thorn Charitable Trust.

\section{Conflicts of Interest}

None.

\section{Ethical Standards}

The authors assert that all procedures contributing to this work comply with the ethical standards of the relevant national and institutional committees on human experimentation and with the Helsinki Declaration of 1975, as revised in 2008. 


\section{References}

Achenbach TM, Rescorla LA (2000). Manual for the ASEBA preschool forms \& profiles. University of Vermont, Research Center for Children, Youth, \& Families: Burlington, VT. Alexander N, Rosenlöcher F, Dettenborn L, Stalder T, Linke J, Distler W, Morgner J, Miller R, Kliegel M, Kirschbaum C (2016). Impact of Antenatal Glucocorticoid Therapy and Risk of Preterm Delivery on Intelligence in Term-Born Children. The Journal of Clinical Endocrinology \& Metabolism 101, 581-589.

Alexander N, Rosenlöcher F, Stalder T, Linke J, Distler W, Morgner J, Kirschbaum C (2012). Impact of Antenatal Synthetic Glucocorticoid Exposure on Endocrine Stress Reactivity in TermBorn Children. Journal of Clinical Endocrinology and Metabolism 97, 3538-3544.

Asztalos E, Willan A, Murphy K, Matthews S, Ohlsson A, Saigal S, Armson A, Kelly E, Delisle M-F, Gafni A, Lee S, Sananes R, Rovet J, Guselle P, Amankwah K (2014). Association between gestational age at birth, antenatal corticosteroids, and outcomes at 5 years: multiple courses of antenatal corticosteroids for preterm birth study at 5 years of age (MACS-5). BMC Pregnancy and Childbirth 14, 272.

Austin PC (2011). An Introduction to Propensity Score Methods for Reducing the Effects of Confounding in Observational Studies. . Taylor \& Francis Multivariate behavioral research 46, $399-424$.

Beck A, Steer R, Brown G (1996). Manual for the Beck depression inventory-II. Psychological Corporation: San Antonio, TX.

\section{Blencowe H, Cousens S, Oestergaard MZ, Chou D, Moller A-B, Narwal R, Adler A, Vera} Garcia C, Rohde S, Say L, Lawn JE (2012). National, regional, and worldwide estimates of preterm birth rates in the year 2010 with time trends since 1990 for selected countries: a systematic analysis and implications. Lancet 379, 2162-72. 
Boes AD, McCormick LM, Coryell WH, Nopoulos P (2008). Rostral Anterior Cingulate Cortex Volume Correlates with Depressed Mood in Normal Healthy Children. Biological Psychiatry 63, 391-397.

Burgess N, Maguire EA, O’Keefe J (2002). The human hippocampus and spatial and episodic memory. Neuron 35, 625-641.

Charkaluk M-L, Rousseau J, Calderon J, Bernard JY, Forhan A, Heude B, Kaminski M (2017). Ages and Stages Questionnaire at 3 Years for Predicting IQ at 5-6 Years. Pediatrics 139, e20162798.

Conover JC, Yancopoulos GD (1997). Neurotrophin Regulation of the Developing Nervous System: Analyses of Knockout Mice. Reviews in the Neurosciences $\mathbf{8}$

Damsted SK, Born AP, Paulson OB, Uldall P (2011). Exogenous glucocorticoids and adverse cerebral effects in children. European Journal of Paediatric Neurology 15, 465-477.

Davis EP, Sandman CA, Buss C, Wing DA, Head K (2013). Fetal Glucocorticoid Exposure Is Associated with Preadolescent Brain Development. Biological Psychiatry 74, 647-655.

Filgueiras A, Pires P, Maissonette S, Landeira-Fernandez J (2013). Psychometric properties of the Brazilian-adapted version of the Ages and Stages Questionnaire in public child daycare centers. Early Human Development 89, 561-576.

Geuze E, Vermetten E, Bremner JD (2005). MR-based in vivo hippocampal volumetrics: 2. Findings in neuropsychiatric disorders. Molecular Psychiatry 10, 160-184.

Girchenko P, Hämäläinen E, Kajantie E, Pesonen A-K, Villa P, Laivuori H, Räikkönen K, Entringer S, Buss C, Wadhwa PD, Hämäläinen E, Kajantie E, Pesonen A-K, Villa PM, Laivuori H, Räikkönen K (2017). Prediction and Prevention of Preeclampsia and Intrauterine Growth Restriction (PREDO) study. International Journal of Epidemiology 46, 1380-1381g. Goldenberg RL, Culhane JF, Iams JD, Romero R (2008). Epidemiology and causes of preterm birth. The Lancet 371, 75-84. 
Gyamfi-Bannerman C, Thom EA, Blackwell SC, Tita ATNN, Reddy UM, Saade GR, Rouse

DJ, McKenna DS, Clark EASS, Thorp JM, Chien EK, Peaceman AM, Gibbs RS, Swamy GK, Norton ME, Casey BM, Caritis SN, Tolosa JE, Sorokin Y, VanDorsten JP, Jain L (2016). Antenatal Betamethasone for Women at Risk for Late Preterm Delivery. . Massachusetts Medical Society The New England journal of medicine 374, 1311-20.

Hodyl NA, Crawford TM, McKerracher L, Lawrence A, Pitcher JB, Stark MJ (2016). Antenatal steroid exposure in the late preterm period is associated with reduced cord blood neurotrophin-3. Early Human Development 101, 57-62.

Ilg L, Kirschbaum C, Li S-C, Rosenlöcher F, Miller R, Alexander N (2018). Persistent Effects of Antenatal Synthetic Glucocorticoids on Endocrine Stress Reactivity from Childhood to Adolescence. The Journal of Clinical Endocrinology \& Metabolism

Jarde A, Morais M, Kingston D, Giallo R, MacQueen GM, Giglia L, Beyene J, Wang Y, McDonald SD (2016). Neonatal Outcomes in Women With Untreated Antenatal Depression Compared With Women Without Depression. . American Medical Association JAMA Psychiatry 73, 826 .

Kamath-Rayne BD, Rozance PJ, Goldenberg RL, Jobe AH (2016). Antenatal corticosteroids beyond 34 weeks gestation: What do we do now? American Journal of Obstetrics and Gynecology 215, 423-430.

Kapoor A, Petropoulos S, Matthews SG (2008). Fetal programming of hypothalamic-pituitaryadrenal (HPA) axis function and behavior by synthetic glucocorticoids. Brain Research Reviews $\mathbf{5 7}$, $586-595$.

Kerstjens JM, Bos AF, ten Vergert EMJ, de Meer G, Butcher PR, Reijneveld SA (2009).

Support for the global feasibility of the Ages and Stages Questionnaire as developmental screener. Early Human Development 85, 443-447.

Khalife N, Glover V, Taanila A, Ebeling H, Järvelin M-R, Rodriguez A (2013). Prenatal 
glucocorticoid treatment and later mental health in children and adolescents. PloS one $\mathbf{8}$, e81394.

Lahti M, Savolainen K, Tuovinen S, Pesonen A-K, Lahti J, Heinonen K, Hämäläinen E, Laivuori H, Villa PM, Reynolds RM, Kajantie E, Räikkönen K (2017). Maternal depressive symptoms during and after pregnancy and psychiatric problems in children. Journal of the American Academy of Child \& Adolescent Psychiatry 56, 30-39.

Lee BK, Lessler J, Stuart EA (2011). Weight trimming and propensity score weighting. PloS one 6, e18174.

Lupien SJ, McEwen BS, Gunnar MR, Heim C (2009). Effects of stress throughout the lifespan on the brain, behaviour and cognition. Nature reviews. Neuroscience 10, 434-45.

March of Dimes, PMNCH S the C, WHO (2012). Born too soon. The Global Action Report on Preterm Birth. CP Howson, MV Kinney, JE Lawn Eds. World Health Organization Publ. Geneva, $1-126$.

Modi N, Lewis H, Al-Naqeeb N, Ajayi-Obe M, Doré CJ, Rutherford M (2001). The Effects of Repeated Antenatal Glucocorticoid Therapy on the Developing Brain. Pediatric Research 50, 581585.

Noguchi K (2014). Glucocorticoid Induced Cerebellar Toxicity in the Developing Neonate: Implications for Glucocorticoid Therapy during Bronchopulmonary Dysplasia. Cells 3, 36-52. Noorlander CW, de Graan PNE, Middeldorp J, Van Beers JJBC, Visser GHA (2006). Ontogeny of hippocampal corticosteroid receptors: Effects of antenatal glucocorticoids in human and mouse. J Comp Neurol 499, 924-932.

Noorlander CW, Tijsseling D, Hessel EVS, de Vries WB, Derks JB, Visser GHA, de Graan PNE (2014). Antenatal Glucocorticoid Treatment Affects Hippocampal Development in Mice. PLoS ONE 9, e85671.

O’Halloran CJ, Kinsella GJ, Storey E (2012). The cerebellum and neuropsychological functioning: a critical review. Journal of clinical and experimental neuropsychology 34, 35-56. 
Pavlík A, Buresová M, Burešová M (1984). The neonatal cerebellum: The highest level of glucocorticoid receptors in the brain. Developmental Brain Research 12, 13-20.

Pihkala J, Hakala T, Petri V, Raivio K (1989). Uudet suomalaiset sikiön kasvukäyrät. Duodecim 105, 1540-1546.

Radloff LS (1977). The CES-D scale: a self-report depression scale for research in the general population. Applied Psychological Measurement 1, 385-401.

Reul JMHM, De Kloet ER (1985). Two Receptor Systems for Corticosterone in Rat Brain: Microdistribution and Differential Occupation. Endocrinology 117, 2505-2511.

Reynolds RM, Seckl JR (2012). Antenatal glucocorticoid treatment: Are we doing harm to term babies? Journal of Clinical Endocrinology and Metabolism 97, 3457-3459.

Rosenberg TJ, Garbers S, Lipkind H, Chiasson MA (2005). Maternal obesity and diabetes as risk factors for adverse pregnancy outcomes: Differences among 4 racial/ethnic groups. American Journal of Public Health 95, 1545-1551.

Saccone G, Berghella V (2016). Antenatal corticosteroids for maturity of term or near term fetuses: systematic review and meta-analysis of randomized controlled trials. . British Medical Journal Publishing Group BMJ (Clinical research ed.) 355, i5044.

Seckl JR, Meaney MJ (2004). Glucocorticoid programming. Ann N Y Acad Sci 1032, 63-84. Squires J, Bricker D, Potter L (1997). Revision of a parent-completed development screening tool: Ages and stages questionniare. Pediatric Psychology 22, 313-328.

Steenis LJP, Verhoeven M, Hessen DJ, van Baar AL (2015). Parental and professional assessment of early child development: The ASQ-3 and the Bayley-III-NL. Early Human Development 91, 217-225.

Stutchfield P (2005). Antenatal betamethasone and incidence of neonatal respiratory distress after elective caesarean section: pragmatic randomised trial. Bmj 331, 662-0.

Stutchfield PR, Whitaker R, Gliddon AE, Hobson L, Kotecha S, Doull IJM (2013). 
Behavioural, educational and respiratory outcomes of antenatal betamethasone for term caesarean section (ASTECS trial). Archives of Disease in Childhood. Fetal and Neonatal Edition 98, F195200.

Sund R (2012). Quality of the Finnish Hospital Discharge Register: A systematic review. . SAGE PublicationsSage UK: London, England Scandinavian Journal of Public Health 40, 505-515.

Sweet DG, Carnielli V, Greisen G, Hallman M, Ozek E, Plavka R, Saugstad OD, Simeoni U, Speer CP, Vento M, Visser GHA, Halliday HL (2017). European Consensus Guidelines on the Management of Respiratory Distress Syndrome - 2016 Update. . Karger Publishers Neonatology 111, 107-125.

The American College of Obstetricians and Gynecologists (2016). ACOG Practice Bulletin 171: Management of preterm labor. Obstetrics \& Gynecology 128, e155-e164.

Tuovinen S, Lahti-Pulkkinen M, Girchenko P, Lipsanen J, Lahti J, Heinonen K, Reynolds RM, Hämäläinen E, Kajantie E, Laivuori H, Pesonen A-K, Villa PM, Räikkönen K (2018). Maternal depressive symptoms during and after pregnancy and child developmental milestones. . Wiley-Blackwell Depression and Anxiety

Uotila J, Vuorela P, Koistinen E, Nupponen I, Nuutila M, Raudaskoski T, Tammela O, Varesmaa-Korhonen L, Working group set up by the Finnish Medical Society Duodecim and the Finnish Gynecologial Association (2011). Preterm Birth: Current Care Guidelines. . The Finnish Medical Society Duodecim: Helsinki

van der Voorn B, Wit JM, van der Pal SM, Rotteveel J, Finken MJJ (2015). Antenatal Glucocorticoid Treatment and Polymorphisms of the Glucocorticoid and Mineralocorticoid Receptors are Associated with IQ and Behavior in Young Adults Born Very Preterm. The Journal of Clinical Endocrinology \& Metabolism 100, 500-7. 
Table 1. Characteristics of the sample according to antenatal exposure to betamethasone. Characteristics are shown for the sample with data available on child's mental and behavioral disorder diagnoses from the child's birth in 2006-2010 to December $31^{\text {st }} 2016$ and for the sample with mother-reported child psychiatric problems and developmental milestones data available at the child age of 1.9 to 5.9 years.

\begin{tabular}{|c|c|c|c|c|c|c|c|c|c|c|c|c|}
\hline & \multicolumn{6}{|c|}{$\begin{array}{c}\text { Sample with data available on mental and behavioral } \\
\text { disorders of the child }\end{array}$} & \multicolumn{6}{|c|}{$\begin{array}{l}\text { Sample with data available on mother-reported psychiatric } \\
\text { proglems and developmental milestones of the child }\end{array}$} \\
\hline & \multirow[b]{2}{*}{$\mathbf{N}$} & \multicolumn{2}{|c|}{$\begin{array}{l}\text { Betamethasone- } \\
\text { exposed } \\
(\mathrm{N}=117) \\
\end{array}$} & \multicolumn{2}{|c|}{$\begin{array}{l}\text { Betamethasone } \\
\text { non-exposed } \\
(\mathrm{N}=\mathbf{4 , 5 9 1 )}\end{array}$} & \multirow[b]{2}{*}{$p$} & \multirow[b]{2}{*}{$\mathbf{N}$} & \multicolumn{2}{|c|}{$\begin{array}{l}\text { Betamethasone- } \\
\text { exposed } \\
(\mathrm{N}=61)\end{array}$} & \multicolumn{2}{|c|}{$\begin{array}{l}\text { Betamethasone } \\
\text { non-exposed } \\
(\mathrm{N}=2,579)\end{array}$} & \multirow[b]{2}{*}{$p$} \\
\hline & & Mean/N & $\mathrm{SD} / \%$ & Mean/N & $\mathrm{SD} / \%$ & & & Mean/N & $\mathrm{SD} / \%$ & Mean/N & SD/\% & \\
\hline \multicolumn{13}{|l|}{ Maternal characteristics } \\
\hline Age at delivery & 4,708 & 32.3 & 5.1 & 31.5 & 4.9 & 0.07 & 2,640 & 32.3 & 5.7 & 31.8 & 4.6 & 0.44 \\
\hline Education (tertiary) & 4,334 & 62 & 54.9 & 2,496 & 59.1 & 0.36 & 2,637 & 35 & 57.4 & 1,615 & 62.7 & 0.40 \\
\hline \multicolumn{13}{|l|}{ Hypertensive disorders } \\
\hline $\begin{array}{l}\text { Chronic hypertension } \\
\text { (yes) }\end{array}$ & 4,708 & 7 & 6.0 & 184 & 4.0 & 0.29 & 2,640 & 6 & 9.8 & 88 & 3.4 & 0.007 \\
\hline Pre-eclampsia (yes) & 4,708 & 21 & 17.9 & 188 & 4.1 & $<0.001$ & 2,640 & 12 & 19.7 & 106 & 4.1 & $<0.001$ \\
\hline $\begin{array}{l}\text { Gestational } \\
\text { hypertension (yes) }\end{array}$ & 4,708 & 11 & 9.4 & 261 & 5.7 & 0.09 & 2,640 & 6 & 9.8 & 138 & 5.4 & 0.13 \\
\hline \multicolumn{13}{|l|}{ Diabetic disorders } \\
\hline Type 1 diabetes (yes) & 4,708 & 6 & 5.1 & 21 & 0.5 & $<0.001$ & 2,640 & 3 & 4.9 & 10 & 0.4 & $<0.001$ \\
\hline $\begin{array}{l}\text { Gestational diabetes } \\
\text { (yes) }\end{array}$ & 4,708 & 18 & 15.4 & 521 & 11.3 & 0.18 & 2,640 & 10 & 16.4 & 276 & 10.7 & 0.16 \\
\hline $\begin{array}{l}\text { Early pregnancy Body } \\
\text { Mass Index (BMI; } \\
\left.\mathrm{kg} / \mathrm{m}^{2}\right)\end{array}$ & 4,708 & 26.0 & 6.3 & 24.5 & 5.0 & 0.01 & 2,640 & 25.9 & 6.6 & 24.3 & 4.8 & 0.06 \\
\hline $\begin{array}{l}\text { Early pregnancy obesity } \\
\left(\mathrm{BMI} \geq 30 \mathrm{~kg} / \mathrm{m}^{2} ; \text { yes }\right)\end{array}$ & 4,708 & 27 & 23.1 & 634 & 13.8 & 0.004 & 2,640 & 11 & 18.0 & 319 & 12.4 & 0.19 \\
\hline History of physician- & 3,411 & 8 & 9.0 & 259 & 7.8 & 0.68 & 2,292 & 5 & 9.1 & 176 & 7.9 & 0.74 \\
\hline
\end{tabular}




\begin{tabular}{|c|c|c|c|c|c|c|c|c|c|c|c|c|}
\hline \multicolumn{13}{|l|}{ diagnosed asthma (yes) } \\
\hline $\begin{array}{l}\text { Smoking during } \\
\text { pregnancy (yes) }\end{array}$ & 4,690 & 9 & 7.8 & 388 & 8.5 & 0.78 & 2,636 & 5 & 8.2 & 162 & 6.3 & 0.55 \\
\hline $\begin{array}{l}\text { Alcohol use during } \\
\text { pregnancy (yes) }\end{array}$ & 3,517 & 13 & 14.3 & 568 & 16.6 & 0.56 & 2,368 & 9 & 16.7 & 390 & 16.9 & 0.97 \\
\hline $\begin{array}{l}\text { Delivery mode } \\
\text { (caesarean section) }\end{array}$ & 4,708 & 50 & 42.7 & 778 & 16.9 & $<0.001$ & 2,640 & 25 & 41.0 & 430 & 16.7 & $<0.001$ \\
\hline $\begin{array}{l}\text { Premature rupture of } \\
\text { membranes (yes) }\end{array}$ & 4,708 & 22 & 18.8 & 75 & 1.6 & $<0.001$ & 2,640 & 6 & 9.8 & 44 & 1.7 & $<0.001$ \\
\hline Parity (primiparous) & 4,708 & 49 & 41.9 & 1,771 & 38.6 & 0.47 & 2,640 & 28 & 45.9 & 1,063 & 41.2 & 0.46 \\
\hline $\begin{array}{l}\text { Any mental and } \\
\text { behavioral disorder } \\
\text { according to ICD-9 or } \\
\text { ICD-10 }\end{array}$ & 4,708 & 22 & 18.8 & 763 & 16.6 & 0.53 & & & & & & \\
\hline $\begin{array}{l}\text { Depressive symptoms } \\
\text { during pregnancy } \\
\text { (trimester weighted } \\
\text { mean score) }\end{array}$ & & & & & & & 2,333 & 13.8 & 7.4 & 11.3 & 6.3 & 0.006 \\
\hline $\begin{array}{l}\text { Depressive symptoms at } \\
\text { child's mean age of } 3.5 \\
\text { years (sum score) }\end{array}$ & & & & & & & 2,557 & 7.9 & 8.5 & 6.4 & 6.2 & 0.16 \\
\hline \multicolumn{13}{|l|}{ Child characteristics } \\
\hline Sex (boy) & 4,708 & 59 & 50.4 & 2,396 & 52.2 & 0.71 & 2,640 & 26 & 42.6 & 1,320 & 51.2 & 0.19 \\
\hline $\begin{array}{l}\text { Age at the end of } \\
\text { register follow-up } \\
\text { (years) }\end{array}$ & 4,708 & 8.0 & 0.9 & 7.7 & 0.8 & $<0.001$ & & & & & & \\
\hline $\begin{array}{l}\text { Age at mother-reported } \\
\text { developmental outcomes } \\
\text { (years) }\end{array}$ & & & & & & & 2,640 & 3.6 & 0.7 & 3.5 & 0.7 & 0.08 \\
\hline Gestational age (weeks) & 4,708 & 36.2 & 3.9 & 40.0 & 1.4 & $<0.001$ & 2,640 & 36.7 & 3.9 & 40.0 & 1.4 & $<0.001$ \\
\hline
\end{tabular}




\begin{tabular}{|c|c|c|c|c|c|c|c|c|c|c|c|c|}
\hline $\begin{array}{l}\text { Preterm birth (birth <37 } \\
\text { weeks of gestation) }\end{array}$ & 4,708 & 61 & 52.1 & 126 & 2.7 & $<0.001$ & 2,640 & 28 & 45.9 & 75 & 2.9 & $<0.001$ \\
\hline Birth weight (grams) & 4,708 & 2,664 & 952 & 3,554 & 489 & $<0.001$ & 2,640 & 2,853 & 962 & 3,545 & 485 & $<0.001$ \\
\hline $\begin{array}{l}\text { Birth weight } \\
\text { standardized by sex and } \\
\text { gestational age } \\
\text { according to Finnish } \\
\text { growth charts (SD units) }\end{array}$ & 4,708 & -0.7 & 1.2 & -0.0 & 1.0 & $<0.001$ & 2,640 & -0.4 & 1.2 & -0.1 & 1.0 & 0.004 \\
\hline $\begin{array}{l}\text { Small-for-gestational } \\
\text { age in birth weight }\end{array}$ & 4,708 & 15 & 12.8 & 90 & 2.0 & $<0.001$ & 2,640 & 4 & 6.6 & 53 & 2.1 & 0.02 \\
\hline Birth length (cm) & 4,708 & 46.0 & 5.1 & 50.3 & 2.1 & $<0.001$ & 2,640 & 46.7 & 5.1 & 50.2 & 2.1 & $<0.001$ \\
\hline $\begin{array}{l}\text { Birth length } \\
\text { standardized by sex and } \\
\text { gestational age } \\
\text { according to Finnish } \\
\text { growth charts (SD units) }\end{array}$ & 4,708 & -0.6 & 1.5 & -0.1 & 1.0 & 0.001 & 2,640 & -0.5 & 1.4 & -0.1 & 1.0 & 0.07 \\
\hline $\begin{array}{l}\text { Small-for-gestational } \\
\text { age in birth length }\end{array}$ & 4,708 & 19 & 16.2 & 157 & 3.4 & $<0.001$ & 2,640 & 8 & 13.1 & 93 & 3.6 & $<0.001$ \\
\hline $\begin{array}{l}\text { Head circumference at } \\
\text { birth }(\mathrm{cm})\end{array}$ & 4,708 & 32.7 & 3.1 & 35.1 & 1.5 & $<0.001$ & 2,640 & 33.2 & 3.2 & 35.1 & 1.5 & $<0.001$ \\
\hline $\begin{array}{l}\text { Head circumference at } \\
\text { birth standardized by sex } \\
\text { and gestational age } \\
\text { according to Finnish } \\
\text { growth charts (SD units) }\end{array}$ & 4,708 & -0.1 & 1.3 & -0.0 & 1.0 & 0.41 & 2,640 & -0.0 & 1.3 & -0.1 & 1.0 & 0.80 \\
\hline $\begin{array}{l}\text { Small-for-gestational } \\
\text { age in birth head } \\
\text { circumference }\end{array}$ & 4,708 & 4 & 3.4 & 88 & 1.9 & 0.25 & 2,640 & 3 & 4.9 & 55 & 2.1 & 0.14 \\
\hline
\end{tabular}

The differences between the betamethasone-exposed and non-exposed groups are determined using t-tests for continuous variables and chisquared test for categorized variables. 


\begin{tabular}{|c|c|c|c|c|c|c|c|c|c|c|c|c|c|}
\hline \multirow{2}{*}{$\begin{array}{l}\text { International Classification of } \\
\text { Disorders, tenth revision (ICD-10) } \\
\text { diagnoses }\end{array}$} & \multicolumn{2}{|c|}{$\begin{array}{l}\text { Betametha } \\
\text { sone- } \\
\text { exposed }\end{array}$} & \multicolumn{2}{|c|}{$\begin{array}{l}\text { Betametha } \\
\text { sone non- } \\
\text { exposed }\end{array}$} & \multicolumn{2}{|c|}{ Model 1} & \multirow[b]{2}{*}{$p$} & \multicolumn{2}{|c|}{ Model 2} & \multirow[b]{2}{*}{$p$} & \multicolumn{2}{|c|}{ Model 3} & \multirow[b]{2}{*}{$p$} \\
\hline & $\mathbf{N}$ & $\%$ & $\mathbf{N}$ & $\%$ & $\begin{array}{l}\text { Odds } \\
\text { Ratio }\end{array}$ & $\begin{array}{l}95 \% \\
\text { CI }\end{array}$ & & $\begin{array}{l}\text { Odds } \\
\text { Ratio }\end{array}$ & $\begin{array}{l}95 \% \\
\text { CI }\end{array}$ & & $\begin{array}{l}\text { Odds } \\
\text { Ratio }\end{array}$ & $\begin{array}{l}95 \% \\
\text { CI }\end{array}$ & \\
\hline $\begin{array}{l}\text { Any mental and behavioral disorder (F00- } \\
\text { F99) }\end{array}$ & 24 & 20.5 & 386 & 8.4 & 2.76 & $\begin{array}{l}1.76 \\
4.32 \\
\end{array}$ & $<0.001$ & 2.56 & $\begin{array}{l}1.50 \\
4.38 \\
\end{array}$ & $<0.001$ & 2.58 & $\begin{array}{l}1.50 \\
4.42 \\
\end{array}$ & $<0.001$ \\
\hline \multicolumn{14}{|l|}{ ICD-10 main diagnosis categories } \\
\hline $\begin{array}{l}\text { Disorders of psychological development } \\
\text { (F80-F89) }\end{array}$ & 19 & 16.2 & 238 & 5.2 & 3.61 & $\begin{array}{l}2.19 \\
5.95\end{array}$ & $<0.001$ & 3.59 & $\begin{array}{l}1.96 \\
6.59\end{array}$ & $<0.001$ & 3.57 & $\begin{array}{l}1.94 \\
6.59\end{array}$ & $<0.001$ \\
\hline $\begin{array}{l}\text { Behavioral and emotional disorders with } \\
\text { onset usually occurring in childhood and } \\
\text { adolescence (F90-F98) }\end{array}$ & 14 & 12.0 & 184 & 4.0 & 3.29 & $\begin{array}{l}1.86 \\
5.82\end{array}$ & $<0.001$ & 2.61 & $\begin{array}{l}1.28 \\
5.31\end{array}$ & 0.008 & 2.66 & $\begin{array}{l}1.30 \\
5.46\end{array}$ & 0.007 \\
\hline \multicolumn{14}{|l|}{$\begin{array}{l}\text { Number of co-morbid ICD-10 main } \\
\text { category diagnoses }\end{array}$} \\
\hline ( & 12 & 10.3 & 293 & 6.4 & 1.80 & $\begin{array}{l}0.99 \\
3.25\end{array}$ & 0.05 & 1.66 & $\begin{array}{l}0.14 \\
1.10\end{array}$ & 0.16 & 1.67 & $\begin{array}{l}0.82 \\
3.41\end{array}$ & 0.16 \\
\hline $2-4$ & 12 & 10.3 & 93 & 2.0 & 6.04 & $\begin{array}{l}3.25 \\
11.27\end{array}$ & $<0.001$ & 4.31 & $\begin{array}{l}1.82, \\
10.19\end{array}$ & $<0.001$ & 4.57 & $\begin{array}{l}1.91 \\
10.95\end{array}$ & $<0.001$ \\
\hline
\end{tabular}

Only disorders which included children in the betamethasone-exposed and non-exposed groups born preterm and at term were included in the analyses. In the analyses with the number of co-morbid ICD-10 main category diagnoses, the group with no mental and behavioral disorders was used as referent.

All models include propensity score weights.

Model 1: adjusted for child sex and birth year.

Model 2: adjusted for model $1+$ maternal early pregnancy body mass index $\left(\mathrm{kg} / \mathrm{m}^{2}\right)$, hypertensive (gestational hypertension, pre-eclampsia, chronic hypertension) and diabetic (gestational diabetes, type 1 diabetes) pregnancy and pre-pregnancy disorders, delivery mode (vaginal/caesarean section), premature rupture of membranes (yes/no), mother's age (years), education (upper/lower tertiary/other), parity (primiparous/multiparous), maternal smoking during pregnancy (no/quit or smoked throughout), maternal alcohol use during pregnancy (yes/no), maternal history of physician-diagnosed asthma (yes/no), child's gestational age (weeks), birth weight standardized by sex and gestational age according to Finnish growth charts(21) (SD units).

Model 3: adjusted for model $2+$ maternal mental and behavioral disorder (any diagnosis/no diagnosis). 


\begin{tabular}{|c|c|c|c|c|c|c|c|c|c|}
\hline \multirow[b]{2}{*}{ Psychiatric problems } & \multicolumn{2}{|c|}{ Model $1(\mathrm{~N}=2,581)$} & & \multicolumn{2}{|c|}{ Model $2(\mathrm{~N}=2,581)$} & & \multicolumn{2}{|c|}{ Model 3 (N=2,257) } & \multirow[b]{2}{*}{\begin{tabular}{|l|}
$p$ \\
$p$ \\
\end{tabular}} \\
\hline & $\begin{array}{l}\text { Mean } \\
\text { difference } \\
\text { between } \\
\text { the } \\
\text { exposed } \\
\text { and non- } \\
\text { exposed } \\
\text { group in } \\
\text { SD units }\end{array}$ & $95 \% \mathrm{CI}$ & $p$ & $\begin{array}{l}\text { Mean } \\
\text { difference } \\
\text { between } \\
\text { the } \\
\text { exposed } \\
\text { and non- } \\
\text { exposed } \\
\text { group in } \\
\text { SD units }\end{array}$ & $95 \% \mathrm{CI}$ & $p$ & $\begin{array}{l}\text { Mean } \\
\text { difference } \\
\text { between } \\
\text { the } \\
\text { exposed } \\
\text { and non- } \\
\text { exposed } \\
\text { group in } \\
\text { SD units }\end{array}$ & $95 \% \mathrm{CI}$ & \\
\hline Total Problems & 0.39 & $0.15,0.64$ & 0.002 & 0.35 & $0.09,0.61$ & 0.008 & 0.31 & $0.05,0.56$ & 0.02 \\
\hline Internalizing Problems & 0.33 & $0.09,0.58$ & 0.008 & 0.29 & $0.03,0.55$ & 0.03 & 0.28 & $0.03,0.54$ & 0.03 \\
\hline Externalizing Problems & 0.38 & $0.13,0.62$ & 0.003 & 0.34 & $0.08,0.60$ & 0.01 & 0.29 & $0.03,0.55$ & 0.03 \\
\hline
\end{tabular}

All models include propensity score weights.

Model 1: adjusted for child sex (boy/girl) and age (months)

Model 2: model $1+$ maternal early pregnancy body mass index $\left(\mathrm{kg} / \mathrm{m}^{2}\right)$, hypertensive (gestational hypertension, pre-eclampsia, chronic hypertension) and gestational (gestational diabetes, type 1 diabetes) pregnancy and pre-pregnancy disorders, delivery mode (vaginal/caesarean section), mother's age (years), education (tertiary/other), parity (primiparous vs. multiparous), premature rupture of membranes (yes/no), maternal smoking during pregnancy (no/quit or smoked throughout), maternal alcohol use during pregnancy (yes/no), maternal history of physician-diagnosed asthma (yes/no), child's gestational age (weeks), birth weight standardized by sex and gestational age according to Finnish growth charts (Pihkala et al. 1989) (SD units).

Model 3: model $2+$ trimester-weighted mean score of maternal depressive symptoms during pregnancy and maternal depressive symptoms at the time of rating the child behavior. 


\begin{tabular}{|c|c|c|c|c|c|c|c|c|c|c|c|c|c|c|}
\hline \multirow{4}{*}{$\begin{array}{l}\text { Developmental } \\
\text { milestones domains }\end{array}$} & \multicolumn{14}{|c|}{ No developmental delay (>-1SD as reference group) vs. } \\
\hline & \multicolumn{7}{|c|}{ Mild developmental delay (-2SD $>-\leq-1 S D)$} & \multicolumn{7}{|c|}{$\begin{array}{l}\text { Fails to meet development typical for child's age }(\leq- \\
\text { 2SD) }\end{array}$} \\
\hline & \multicolumn{2}{|c|}{$\begin{array}{l}\text { Betametha } \\
\text { sone- } \\
\text { exposed }\end{array}$} & \multicolumn{2}{|c|}{$\begin{array}{l}\text { Betametha } \\
\text { sone non- } \\
\text { exposed }\end{array}$} & \multirow[t]{2}{*}{$\begin{array}{l}\text { Odds } \\
\text { Ratio }\end{array}$} & \multirow[t]{2}{*}{$95 \% \mathrm{CI}$} & \multirow[t]{2}{*}{$p$} & \multicolumn{2}{|c|}{$\begin{array}{l}\text { Betametha } \\
\text { sone- } \\
\text { exposed }\end{array}$} & \multicolumn{2}{|c|}{$\begin{array}{l}\text { Betametha } \\
\text { sone non- } \\
\text { exposed }\end{array}$} & \multirow[t]{2}{*}{$\begin{array}{l}\text { Odds } \\
\text { Ratio }\end{array}$} & \multirow[t]{2}{*}{$95 \% \mathrm{CI}$} & \multirow[t]{2}{*}{$p$} \\
\hline & $\mathbf{N}$ & $\%$ & $\mathbf{N}$ & $\%$ & & & & $\mathbf{N}$ & $\%$ & $\mathbf{N}$ & $\%$ & & & \\
\hline \multicolumn{15}{|l|}{$\begin{array}{l}\text { Communication } \\
\text { skills }\end{array}$} \\
\hline Model $1(\mathrm{~N}=2,470)$ & 4 & 6.6 & 129 & 5.0 & 1.54 & $0.56,4.21$ & 0.40 & 5 & 8.2 & 96 & 3.7 & 2.64 & $1.06,6.56$ & 0.04 \\
\hline Model $2(\mathrm{~N}=2,470)$ & 4 & 6.6 & 129 & 5.0 & 1.26 & $0.42,3.79$ & 0.68 & 5 & 8.2 & 96 & 3.7 & 1.69 & $0.57,5.04$ & 0.35 \\
\hline Model $3(\mathrm{~N}=2,146)$ & 4 & 7.8 & 115 & 5.2 & 1.28 & $0.41,4.00$ & 0.68 & 5 & 9.8 & 90 & 4.1 & 1.63 & $0.54,4.94$ & 0.38 \\
\hline \multicolumn{15}{|l|}{ Fine motor skills } \\
\hline Model $1(\mathrm{~N}=2,455)$ & 6 & 9.8 & 208 & 8.1 & 1.44 & $0.61,3.39$ & 0.40 & 4 & 6.6 & 117 & 4.5 & 1.75 & $0.64,4.81$ & 0.28 \\
\hline Model $2(\mathrm{~N}=2,455)$ & 6 & 9.8 & 208 & 8.1 & 1.08 & $0.42,2.76$ & 0.88 & 4 & 6.6 & 117 & 4.5 & 1.27 & $0.40,4.03$ & 0.69 \\
\hline Model $3(\mathrm{~N}=2,139)$ & 5 & 9.8 & 181 & 8.2 & 1.15 & $0.42,3.17$ & 0.79 & 3 & 5.9 & 109 & 4.9 & 0.99 & $0.27,3.72$ & 0.99 \\
\hline \multicolumn{15}{|l|}{ Gross motor skills } \\
\hline Model $1(\mathrm{~N}=2,469)$ & 4 & 6.6 & 177 & 6.9 & 1.01 & $0.38,2.74$ & 0.98 & 5 & 8.8 & 128 & 5.0 & 1.77 & $0.71,4.42$ & 0.22 \\
\hline Model $2(\mathrm{~N}=2,469)$ & 4 & 6.6 & 177 & 6.9 & 1.00 & $0.34,2.92$ & 1.00 & 5 & 8.8 & 128 & 5.0 & 0.69 & $0.22,2.20$ & 0.53 \\
\hline Model $3(\mathrm{~N}=2,144)$ & 4 & 7.8 & 151 & 6.8 & 1.11 & $0.37,3.31$ & 0.85 & 4 & 7.8 & 112 & 5.0 & 0.68 & $0.19,2.40$ & 0.54 \\
\hline \multicolumn{15}{|l|}{$\begin{array}{l}\text { Problem solving } \\
\text { skills }\end{array}$} \\
\hline Model $1(\mathrm{~N}=2,447)$ & 5 & 8.2 & 159 & 6.2 & 1.69 & $0.68,4.18$ & 0.26 & 8 & 13.1 & 113 & 4.4 & 3.74 & $1.76,7.94$ & $<0.001$ \\
\hline Model $2(\mathrm{~N}=2,447)$ & 5 & 8.2 & 159 & 6.2 & 1.61 & $0.60,4.33$ & 0.34 & 8 & 13.1 & 113 & 4.4 & 3.24 & $1.37,7.69$ & 0.008 \\
\hline Model $3(\mathrm{~N}=2,133)$ & 5 & 9.8 & 142 & 6.4 & 1.67 & $0.61,4.52$ & 0.32 & 7 & 13.7 & 103 & 4.6 & 2.45 & $0.93,6.46$ & 0.07 \\
\hline \multicolumn{15}{|l|}{$\begin{array}{l}\text { Personal social } \\
\text { skills }\end{array}$} \\
\hline Model $1(\mathrm{~N}=2,479)$ & 6 & 9.8 & 225 & 8.7 & 1.44 & $0.62,3.34$ & 0.39 & 6 & 9.8 & 92 & 3.6 & 3.70 & $1.56,8.81$ & 0.003 \\
\hline Model $2(\mathrm{~N}=2,479)$ & 6 & 9.8 & 225 & 8.7 & 1.13 & $0.45,2.83$ & 0.80 & 6 & 9.8 & 92 & 3.6 & 3.56 & $1.32,9.58$ & 0.01 \\
\hline Model $3(\mathrm{~N}=2,152)$ & 6 & 11.8 & 197 & 8.9 & 1.43 & $0.56,3.64$ & 0.45 & 6 & 11.8 & 87 & 3.9 & 3.76 & $1.35,10.43$ & 0.01 \\
\hline
\end{tabular}

All models include propensity score weights.

Model 1: adjusted for child sex (boy/girl) and age (months) 
Model 2: model $1+$ maternal early pregnancy body mass index $\left(\mathrm{kg} / \mathrm{m}^{2}\right)$, hypertensive (gestational hypertension, pre-eclampsia, chronic hypertension) and gestational (gestational diabetes, type 1 diabetes) pregnancy and pre-pregnancy disorders, delivery mode (vaginal/caesarean section), mother's age (years), education (tertiary/other), parity (primiparous vs. multiparous), premature rupture of membranes (yes/no), maternal smoking during pregnancy (no/quit or smoked throughout), maternal alcohol use during pregnancy (yes/no), maternal history of physician-diagnosed asthma (yes/no), child's gestational age (weeks), birth weight standardized by sex and gestational age according to Finnish growth charts (Pihkala et al. 1989) (SD units).

Model 3: model $2+$ trimester-weighted mean score of maternal depressive symptoms during pregnancy and maternal depressive symptoms at the time of rating the child development. 
Supplement 1.

\section{Child Behavior Checklist subscale analyses}

\section{Methods}

The Child Behavior Checklist 11/2-5 years (CBCL) yields seven syndrome (emotionally reactive, anxious/depressed, somatic complaints,

withdrawn, sleep problems, attention problems, and aggressive behavior) and five Diagnostic and Statistical Manual of Mental Disorders-IV

(DSM-IV)-oriented scales DSM-IV-oriented (affective, anxiety, pervasive developmental, attention-deficit/hyperactivity [ADHD], and

oppositional defiant problems) subscales in addition to total, internalizing, and externalizing psychiatric problems scales (Achenbach \& Rescorla 2000).

Statistical analyses 
Associations between antenatal betamethasone exposure and CBCL syndrome and DSM-IV-oriented scales were tested by using generalized linear models with Gaussian reference distribution Raw scores were used in all analyses with the syndrome and DSM-IV-oriented scales, as recommended in the manual for the CBCL (Achenbach \& Rescorla 2000). The variables were square-root transformed to obtain normality and converted into standard deviation (SD) units with a mean of 0 and SD of 1 to provide comparable effect size estimates. We used propensity score weighing (Austin 2011) in all analyses to account for observed covariates that were associated with betamethasone treatment.

All analyses included the propensity score weights and were first adjusted for child's sex and age at follow-up (model 1), and then for maternal early pregnancy BMI, hypertensive and diabetic pregnancy and pre-pregnancy disorders, delivery mode, mother's age at delivery, education, parity, premature rupture of membranes, smoking and alcohol use during pregnancy, past or present physician-diagnosed asthma, and child's birth weight SD score and gestational age (model 2). In the last model we made adjustments for maternal depressive symptoms during pregnancy and at the time of rating the child (model 3).

Finally, we entered an interaction term 'betamethasone exposure/non-exposure x preterm/term birth' into the equations to study if the betamethasone effects varied by preterm/term status, and an interaction term 'betamethasone exposure/non-exposure x girl/boy' into the equations to study if the betamethasone effects varied by child's sex. 


\section{Results}

Betamethasone-exposure was associated with higher scores on emotionally reactive, withdrawn, attention problems, aggressive behavior, anxiety problems, pervasive developmental problems and ADHD problems scales (see Table S2, available online). These differences persisted across the different adjustment models including the propensity score weights, except for aggressive problems and anxiety problems which attenuated to nonsignificant in model 3 and model 2, respectively (see Table S2, available online).

The interaction analyses ‘betamethasone-exposure/non-exposure x preterm/term birth' revealed three significant interactions: These were found on the withdrawn problems, sleep problems, and anxiety problems scales ( $p$-values for interaction=0.03, 0.008 , and 0.007 , respectively; $p$ values $>0.06$ for the other interactions in the analyses of the other psychiatric problems scales). Sub-analyses, separately in those born preterm and term revealed that in the preterm group, exposure to betamethasone was associated with lower scores on sleep problems than $(B=-0.40,95 \%$ $\mathrm{CI}=-0.79$ to $-0.01, p=0.045)$, however in the term group the exposed and non-exposed children did not differ significantly $(p=0.10)$. Yet, in the term group, betamethasone-exposure was associated with higher scores on withdrawn and anxiety problems $(\mathrm{B}=0.50,95 \% \mathrm{CI}=0.16$ to 0.83 , $p=0.004 ; \mathrm{B}=0.50,95 \% \mathrm{CI}=0.17$ to $0.84, p=0.004$, respectively), while among children born preterm, the exposed and non-exposed groups did not differ significantly ( $p$-values $>0.30)$. 
In the interaction analyses with 'betamethasone exposure vs. non-exposure $\mathrm{x}$ sex', we found one significant interaction; for aggressive behavior ( $p=0.04$ for interaction) ( $p$-values $>0.20$ for interactions in the analyses of the other psychiatric problems scales). Analyses in boys and girls separately showed that in boys, betamethasone-exposure was associated with higher scores on aggressive behavior $(\mathrm{B}=0.61,95 \% \mathrm{CI}=0.24$ to $0.98, p=0.001)$; exposed and non-exposed girls did not differ on this scale ( $p$-value $=0.54)$.

\section{References}

Achenbach TM, Rescorla LA (2000). Manual for the ASEBA preschool forms \& profiles. University of Vermont, Research Center for Children, Youth, \& Families: Burlington, VT.

Austin PC (2011). An Introduction to Propensity Score Methods for Reducing the Effects of Confounding in Observational Studies. . Taylor \& Francis Multivariate behavioral research 46, 399-424. 


\begin{tabular}{|c|c|c|c|c|c|c|}
\hline \multicolumn{7}{|c|}{$\begin{array}{l}\text { Supplementary Table S1. Number and percentage of diagnoses of mental and behavioral disorders } \\
\text { according to the International Classification of Diseases-10 in the betamethasone-exposed and non-exposed } \\
\text { groups in the analytic sample. }\end{array}$} \\
\hline \multirow{3}{*}{$\begin{array}{l}\text { International } \\
\text { Classification of } \\
\text { Disorders, tenth revision } \\
\text { (ICD-10) diagnoses }\end{array}$} & \multicolumn{2}{|c|}{ All } & \multicolumn{2}{|c|}{ Term } & \multicolumn{2}{|c|}{ Preterm } \\
\hline & $\begin{array}{l}\text { Betametha } \\
\text { sone- } \\
\text { exposed } \\
(\mathrm{N}=117) \\
\end{array}$ & $\begin{array}{l}\text { Betametha } \\
\text { sone non- } \\
\text { exposed } \\
(\mathrm{N}=\mathbf{4 , 5 9 1 )} \\
\end{array}$ & $\begin{array}{l}\text { Betametha } \\
\text { sone- } \\
\text { exposed } \\
(\mathrm{N}=56) \\
\end{array}$ & $\begin{array}{l}\text { Betametha } \\
\text { sone non- } \\
\text { exposed } \\
(\mathrm{N}=4,465) \\
\end{array}$ & $\begin{array}{l}\text { Betametha } \\
\text { sone- } \\
\text { exposed } \\
(\mathrm{N}=61) \\
\end{array}$ & $\begin{array}{l}\text { Betametha } \\
\text { sone non- } \\
\text { exposed } \\
(\mathrm{N}=126) \\
\end{array}$ \\
\hline & $\mathbf{N}(\%)$ & $\mathbf{N}(\%)$ & $\mathbf{N}(\%)$ & $\mathrm{N}(\%)$ & $\mathbf{N}(\%)$ & $\mathrm{N}(\%)$ \\
\hline $\begin{array}{l}\text { Any mental and } \\
\text { behavioral disorder (F00- } \\
\text { F99) }\end{array}$ & $24(20.5)$ & $386(8.4)$ & $10(17.9)$ & $373(8.4)$ & $14(23.0)$ & $13(10.3)$ \\
\hline \multicolumn{7}{|l|}{$\begin{array}{l}\text { ICD-10 main diagnosis } \\
\text { categories }\end{array}$} \\
\hline $\begin{array}{l}\text { Schizophrenia, } \\
\text { schizotypal and delusional } \\
\text { disorders (F20-F29) }\end{array}$ & $0(0.0)$ & $2(0.0)$ & $0(0.0)$ & $2(0.0)$ & $0(0.0)$ & $0(0.0)$ \\
\hline $\begin{array}{l}\text { Mood disorders (F30- } \\
\text { F39) }\end{array}$ & $0(0.0)$ & $4(0.1)$ & $0(0.0)$ & $4(0.1)$ & $0(0.0)$ & $0(0.0)$ \\
\hline $\begin{array}{l}\text { Neurotic, stress-related } \\
\text { and somatoform disorders } \\
\text { (F40-F48) }\end{array}$ & $0(0.0)$ & $12(0.3)$ & $0(0.0)$ & $12(0.3)$ & $0(0.0)$ & $0(0.0)$ \\
\hline $\begin{array}{l}\text { Behavioural syndromes } \\
\text { associated with } \\
\text { physiological } \\
\text { disturbances and physical } \\
\text { factors (F50-F59) }\end{array}$ & $2(1.7)$ & $30(0.7)$ & $2(3.6)$ & $30(0.7)$ & $0(0.0)$ & $0(0.0)$ \\
\hline $\begin{array}{l}\text { Disorders of adult } \\
\text { personality and behavior } \\
(\mathrm{F} 60-\mathrm{F} 69)\end{array}$ & $0(0.0)$ & $2(0.0)$ & $0(0.0)$ & $2(0.0)$ & $0(0.0)$ & $0(0.0)$ \\
\hline $\begin{array}{l}\text { Mental retardation (F70- } \\
\text { F79) }\end{array}$ & $3(2.6)$ & $16(0.3)$ & $0(0.0)$ & $16(0.4)$ & $3(4.9)$ & $0(0.0)$ \\
\hline $\begin{array}{l}\text { Disorders of } \\
\text { psychological } \\
\text { development (F80-F89) }\end{array}$ & $19(16.2)$ & $238(5.2)$ & $9(16.1)$ & $231(5.2)$ & $10(16.4)$ & $7(5.6)$ \\
\hline $\begin{array}{l}\text { Behavioral and } \\
\text { emotional disorders with }\end{array}$ & $14(12.0)$ & $184(4.0)$ & $5(8.9)$ & $175(3.9)$ & $9(14.8)$ & $9(7.1)$ \\
\hline
\end{tabular}




\begin{tabular}{|c|c|c|c|c|c|c|}
\hline $\begin{array}{l}\text { onset usually occuring in } \\
\text { childhood and } \\
\text { adolescence (F90-F98) }\end{array}$ & & & & & & \\
\hline $\begin{array}{l}\text { Unspecified mental } \\
\text { disorder (F99) }\end{array}$ & $0(0.0)$ & $1(0.0)$ & $0(0.0)$ & $1(0.0)$ & $0(0.0)$ & $0(0.0)$ \\
\hline \multicolumn{7}{|l|}{$\begin{array}{l}\text { Number of main category } \\
\text { diagnoses }\end{array}$} \\
\hline 0 & $93(79.5)$ & $4,205(91.6)$ & $46(82.1)$ & $4,092(91.6)$ & $47(77.0)$ & $113(89.7)$ \\
\hline 1 & $12(10.3)$ & $293(6.4)$ & $5(8.9)$ & $283(6.3)$ & $7(11.5)$ & $10(7.9)$ \\
\hline $2-4$ & $12(10.3)$ & $93(2.0)$ & $5(8.9)$ & $90(2.0)$ & $7(11.5)$ & $3(2.4)$ \\
\hline \multicolumn{7}{|l|}{ Specific diagnoses } \\
\hline $\begin{array}{l}\text { Nonorganic sleep } \\
\text { disorders (F51) }\end{array}$ & $1(0.9)$ & $20(0.4)$ & $1(1.8)$ & $20(0.4)$ & $0(0.0)$ & $0(0.0)$ \\
\hline $\begin{array}{l}\text { Specific developmental } \\
\text { disorders of speech and } \\
\text { language }(\mathrm{F} 80)\end{array}$ & $8(6.8)$ & $134(2.9)$ & $2(3.6)$ & $130(2.9)$ & $6(9.8)$ & $4(3.2)$ \\
\hline $\begin{array}{l}\text { Specific developmental } \\
\text { disorders of scholastic } \\
\text { skills (F81) }\end{array}$ & $2(1.7)$ & $18(0.4)$ & $2(3.6)$ & $17(0.4)$ & $0(0.0)$ & $1(0.8)$ \\
\hline $\begin{array}{l}\text { Specific developmental } \\
\text { disorder of motor function } \\
(\mathrm{F} 82)\end{array}$ & $3(2.6)$ & $72(1.6)$ & $0(0.0)$ & $70(1.6)$ & $3(4.9)$ & $2(1.6)$ \\
\hline $\begin{array}{l}\text { Mixed specific } \\
\text { developmental disorders } \\
(\mathrm{F} 83)\end{array}$ & $3(2.6)$ & $49(1.1)$ & $0(0.0)$ & $47(1.1)$ & $3(4.9)$ & $2(1.6)$ \\
\hline $\begin{array}{l}\text { Pervasive developmental } \\
\text { disorders (F84) }\end{array}$ & $2(1.7)$ & $30(0.7)$ & $1(1.8)$ & $29(0.6)$ & $1(1.6)$ & $1(0.8)$ \\
\hline $\begin{array}{l}\text { Other disorders of } \\
\text { psychological } \\
\text { development (F88) }\end{array}$ & $5(4.3)$ & $34(0.7)$ & $4(7.1)$ & $33(0.7)$ & $1(1.6)$ & $1(0.8)$ \\
\hline $\begin{array}{l}\text { Unspecified disorder of } \\
\text { psychological } \\
\text { development (F89) }\end{array}$ & $2(1.7)$ & $5(0.1)$ & $2(3.6)$ & $5(0.1)$ & $0(0.0)$ & $0(0.0)$ \\
\hline $\begin{array}{l}\text { Hyperkinetic disorders } \\
\text { (F90) }\end{array}$ & $7(6.0)$ & $62(1.4)$ & $3(5.4)$ & $60(1.3)$ & $4(6.6)$ & $2(1.6)$ \\
\hline
\end{tabular}




\begin{tabular}{|c|l|l|l|l|l|l|}
\hline $\begin{array}{c}\text { Disorders of social } \\
\text { functioning with onset } \\
\text { specific to childhood and } \\
\text { adolescence (F94) }\end{array}$ & $1(0.9)$ & $11(0.2)$ & $1(1.8)$ & $11(0.2)$ & $0(0.0)$ & $0(0.0)$ \\
\hline $\begin{array}{c}\text { Other behavioural and } \\
\text { emotional disorders with } \\
\text { onset usually occurring in } \\
\text { childhood and } \\
\text { adolescence (F98) }\end{array}$ & $6(5.1)$ & $82(1.8)$ & $1(1.8)$ & $77(1.7)$ & $5(8.2)$ & $5(4.0)$ \\
\hline $\begin{array}{c}\text { Conduct disorders (F63, } \\
\text { F90.1, F91-F92) }\end{array}$ & $2(1.7)$ & $27(0.6)$ & $0(0.0)$ & $25(0.6)$ & $2(3.3)$ & $2(1.6)$ \\
\hline $\begin{array}{l}\text { Emotional disorders } \\
\text { (F30-F39, F40-49, F92- } \\
\text { F93) }\end{array}$ & $1(0.9)$ & $67(1.5)$ & $0(0.0)$ & $64(1.4)$ & $1(1.6)$ & $3(2.4)$ \\
\hline
\end{tabular}




\begin{tabular}{|c|c|c|c|c|c|c|}
\hline \multicolumn{7}{|c|}{$\begin{array}{l}\text { Supplementary Table S2. The associations between antenatal betamethasone exposure and mother-reported } \\
\text { child internalizing and externalizing psychiatric problems subscales. }\end{array}$} \\
\hline \multirow[b]{2}{*}{$\begin{array}{l}\text { Psychiatric problems } \\
\text { subscales }\end{array}$} & \multirow[b]{2}{*}{$\begin{array}{l}\text { Model 1 } \\
\text { Mean difference } \\
\text { between the } \\
\text { exposed and non- } \\
\text { exposed group in } \\
\text { standard } \\
\text { deviation units } \\
(95 \% \mathrm{CI}) \\
(\mathrm{N}=\mathbf{2 , 5 8 1})\end{array}$} & \multirow[b]{2}{*}{$p$} & \multirow[b]{2}{*}{$\begin{array}{l}\text { Model } 2 \\
\text { Mean difference } \\
\text { between the } \\
\text { exposed and non- } \\
\text { exposed group in } \\
\text { standard } \\
\text { deviation units } \\
(95 \% \mathrm{CI}) \\
(\mathrm{N}=2,581)\end{array}$} & \multirow[b]{2}{*}{$p$} & \multirow[b]{2}{*}{$\begin{array}{l}\text { Model } 3 \\
\text { Mean difference } \\
\text { between the } \\
\text { exposed and non- } \\
\text { exposed group in } \\
\text { standard } \\
\text { deviation units } \\
(95 \% \mathrm{CI}) \\
(\mathrm{N}=\mathbf{2 , 2 5 7 )}\end{array}$} & \multirow[b]{2}{*}{$P$} \\
\hline & & & & & & \\
\hline \multicolumn{7}{|l|}{ Syndrome scales } \\
\hline Emotionally Reactive & $0.27(0.02,0.52)$ & 0.03 & $0.26(0.00,0.52)$ & 0.049 & $0.28(0.02,0.55)$ & 0.04 \\
\hline Anxious/ Depressed & $0.24(-0.01,0.49)$ & 0.06 & $0.17(-0.09,0.43)$ & 0.20 & $0.17(-0.10,0.45)$ & 0.21 \\
\hline Somatic Complaints & $0.16(-0.09,0.41)$ & 0.20 & $0.09(-0.17,0.35)$ & 0.52 & $0.05(-0.22,0.32)$ & 0.70 \\
\hline Withdrawn & $0.36(0.12,0.61)$ & 0.004 & $0.39(0.13,0.65)$ & 0.003 & $0.42(0.15,0.69)$ & 0.002 \\
\hline Sleep Problems & $0.11(-0.14,0.36)$ & 0.39 & $0.09(-0.17,0.35)$ & 0.50 & $0.01(-0.27,0.28)$ & 0.95 \\
\hline Attention Problems & $0.29(0.04,0.53)$ & 0.02 & $0.33(0.07,0.58)$ & 0.01 & $0.32(0.05,0.59)$ & 0.02 \\
\hline \multicolumn{7}{|l|}{$\begin{array}{l}\text { Diagnostic and Statistical } \\
\text { Manual of Mental } \\
\text { Disorders-IV-oriented } \\
\text { scales }\end{array}$} \\
\hline Aggressive Behavior & $0.32(0.08,0.57)$ & 0.01 & $0.28(0.02,0.54)$ & 0.04 & $0.21(-0.06,0.47)$ & 0.12 \\
\hline Affective Problems & $0.18(-0.07,0.43)$ & 0.15 & $0.12(-0.15,0.38)$ & 0.38 & $0.08(-0.19,0.35)$ & 0.55 \\
\hline Anxiety Problems & $0.29(0.04,0.53)$ & 0.02 & $0.24(-0.02,0.50)$ & 0.07 & $0.23(-0.04,0.50)$ & 0.10 \\
\hline $\begin{array}{l}\text { Pervasive } \\
\text { Developmental Problems }\end{array}$ & $0.42(0.17,0.66)$ & 0.001 & $0.45(0.19,0.71)$ & 0.001 & $0.47(0.21,0.74)$ & $<0.001$ \\
\hline $\begin{array}{l}\text { Attention Deficit } \\
\text { Hyperactivity Disorder } \\
\text { Problems }\end{array}$ & $0.41(0.16,0.65)$ & 0.001 & $0.40(0.14,0.66)$ & 0.002 & $0.33(0.06,0.60)$ & 0.02 \\
\hline $\begin{array}{l}\text { Oppositional Defiant } \\
\text { Problems }\end{array}$ & $0.20(-0.05,0.45)$ & 0.11 & $0.15(-0.11,0.41)$ & 0.27 & $0.11(-0.16,0.38)$ & 0.41 \\
\hline
\end{tabular}


All models include propensity score weights.

Model 1: adjusted for child sex (boy/girl) and age (months)

Model 2: model $1+$ maternal early pregnancy body mass index $\left(\mathrm{kg} / \mathrm{m}^{2}\right)$, hypertensive (gestational hypertension, pre-eclampsia, chronic hypertension) and diabetic (gestational diabetes, type 1 diabetes) pregnancy and pre-pregnancy disorders, delivery mode (vaginal/caesarian section), mother's age (years), education (tertiary/other), parity (primiparous/multiparous), premature rupture of membranes (yes/no), maternal smoking during pregnancy (no/quit or smoked throughout), maternal alcohol use during pregnancy (yes/no), maternal history of physiciandiagnosed asthma (yes/no), child's gestational age (weeks), birth weight standardized by sex and gestational age according to Finnish growth charts $^{1}$ (SD units).

Model 3: model $2+$ trimester-weighted mean score of maternal depressive symptoms during pregnancy and maternal depressive symptoms at the time of rating the child neurobehavior. 
Supplementary Figure S1.

4,777 mothers recruited during pregnancy in 2006-2010

Sample with data available on mental and behavioral disorder diagnoses of the child
Sample with data available on mother-reported

psychiatric problems and developmental milestones of the child

2 withdrew consent

3 children had died

32 did not have data in the

Finnish Medical Birth Registe

55 had declined participation

100 addresses were not traceable

4,585 mothers and their children were invited to participate in

4,585 mothers and their
a follow-up in 2011-2012

a follow-up in 2011-2012

2,667 mother-child dyads participated in the follow-up 1

2,640 eligible mother-child dyads were included in the analytic sample

4,708 eligible children were included in the analytic sample 